Article

\title{
Spatial Planning, Urban Governance and the Economic Context: The Case of 'Mehr' Housing Plan, Iran
}

\author{
Saeed Zanganeh Shahraki ${ }^{1}$, Narges Ahmadifard ${ }^{2}$, Hossein Farhadikhah ${ }^{1}{ }^{1}$, \\ Bagher Fotouhi Mehrabani ${ }^{1}$, Asghar Haydari ${ }^{1}$, Yaghob Abdali ${ }^{1}{ }^{\mathbb{D}}$, Vahid Abbasi Fallah ${ }^{1}$, \\ Ebrahim Farhadi ${ }^{1}$, Sirio Cividino ${ }^{3}$, Sabato Vinci ${ }^{4}$ and Luca Salvati ${ }^{5, *}$ \\ 1 Department of Human Geography, Faculty of Geography, University of Tehran, Tehran 1613778314, Iran; \\ saeed.zanganeh@ut.ac.ir (S.Z.S.); farhadi.khah@ut.ac.ir (H.F.); fotuhi.b@ut.ac.ir (B.F.M.); \\ asghrheadari@ut.ac.ir (A.H.); yaghob.abdali@ut.ac.ir (Y.A.); vahidabbasi@ut.ac.ir (V.A.F.); \\ e.farhadi71@ut.ac.ir (E.F.) \\ 2 Department of Tourism, Lorestan University, Khorramabad 1484678543, Iran; N.Ahmadifard@ut.ac.ir \\ 3 Department of Agriculture, University of Udine, Via del Cotonificio 114, I-33100 Udine, Italy; \\ sirio.cividino@uniud.it \\ 4 Department of Political Science, Third University of Rome, Via G. Chiabrera 199, I-00145 Rome, Italy; \\ sabato.vinci@uniroma3.it \\ 5 Department of Economics and Law, University of Macerata, I-62100 Macerata, Italy \\ * Correspondence: luca.salvati@crea.gov.it
}

Received: 31 March 2020; Accepted: 18 May 2020; Published: 22 May 2020

\begin{abstract}
With the increasing concentration of population and economic activities in metropolitan regions, dwelling shortages and housing quality have become critical issues in urban management. Town plans considering social, economic, political, and cultural features of local communities have been developed with the aim of supporting housing, especially in emerging economies. In Iran, the 'Mehr Housing' Plan has been considered as one of the most relevant strategies for social housing since the 2000s. However, the acceptance of 'Mehr Housing' plans at the community scale has been rather low, reflecting the fact that it is a top-down, non-participatory policy. The present study investigates the most important factors affecting social acceptance of 'Mehr Housing' plans by interviewing 45 experts through a structured questionnaire that evaluated multiple analyses' dimensions of housing and urban planning in Iran. Results showed that six dimensions (physical, institutional-managerial, economic, socio-cultural, legal, and locational) had contributed to social dissatisfaction with 'Mehr Housing' local initiatives. In particular, socio-cultural and legal dimensions were demonstrated to have a large impact on local communities' dissatisfaction.
\end{abstract}

Keywords: satisfaction; social housing; Mehr housing plans; Iran

\section{Introduction}

Housing has been one of the most important human needs throughout history. Since the adoption of the Universal Declaration of Human Rights in 1948, the right to adequate housing has been regarded as one of the essential components of people's standards of living. Since then, governments have laid down specific provisions and established ministries or departments that have formulated policies, regulations, programs, and special projects that allocate funds to public housing [1-3]. Nevertheless, housing is still one of the most acute problems in emerging countries because of internal (and international) migration, poverty, shortages of building land, weak infrastructure planning, and accelerated urbanization [1]. Social housing is a form of housing tenure in which the property is usually 
owned by a government authority, which may be central or local $[4,5]$. It is often considered a potential remedy to housing inequality. Having the final objective of providing affordable housing, this kind of public housing can be managed by the state, non-profit organizations, or a combination of the two agencies [6]. Provision of social housing depends on institutional, political, cultural, and socioeconomic characteristics of each state, being more-or-less finely tuned with housing needs and also taking account of social deprivation within local communities [7]. It is distinct from private housing-a form of housing tenure in which the property is owned by a private developer or non-profit organizations with no direct connection to the state [8]. Public housing has been intrinsically characterized by a terminology, definitions of poverty, technical (bureaucratic) procedures, and other criteria for allocation that vary significantly between different socioeconomic contexts across the world [9].

The Industrial Revolution of the 19th Century led to dramatic population growth, especially in large cities, and spawned the construction of modern social housing. At the beginning of the last century, the United Kingdom was the forerunner of policies and public interventions in housing; the UK government initially financed and developed projects in London and subsequently did so over the whole country [10]. Public housing projects were implemented in some other European countries and the United States from the 1930s onwards, and became widespread after World War II [11]. While increasingly providing a variety of settings and formats, most traditional public housing projects in advanced countries have consisted of one or more blocks of low-rise and/or high-rise apartment buildings, with standardized designs, community spaces and, sometimes, poor standards of construction [7]. More recently, mismanagement at the local level, a lowering of standards for occupancy, technical problems, complicated procedures for allocation, bureaucracy, and diminished political support have become recurrent issues facing social housing in advanced economies $[3,4,8]$.

Being priced well below the market rate, public housing allowed people to live in more convenient locations rather than move away from the city in search of lower rents. This has indirectly prevented homeownership and often reduced social mobility [7]. At the same time, social housing projects have been seen to greatly increase concentrated poverty in local communities, leading to several negative externalities such a high rates of crime and drug use, and educational under-performance, particularly in compact, dense urban areas $[9,10]$. In many cities, public housing has been found to spawn neighborhood social problems because it concentrates welfare-dependent, single-parent families, non-workers, and, on occasion, criminals [11].

Within such a context, transition and emerging economies have been witnessing accelerated urbanization, thereby consolidating their current huge housing deficits [12]. While high costs, low quality of materials, and inadequate construction knowledge prevented low-income households from building homes that are safe and meet sufficient engineering standards, developers fear losing profit by trying to serve a low-margin and high-volume volatile market with quality products and services [13]. Access to finance and a focus on bringing affordable (and where possible environmentally-friendly) housing products and services to the poor have become with priorities for social housing policies in emerging economies, along with promoting a steady local supply of housing products to meet the even increasing demand [14]. Private-public partnerships should be encouraged simultaneously with strategies to avoid the most frequent critical issues and misunderstandings typical of social housing policies in advanced economies [15].

However, bureaucracy, corruption, low compliance to standards, architectural design homologation, poor infrastructure, and concentration of poverty and social deprivation frequently characterize public housing initiatives in emerging countries [7]. Most of these initiatives have been implemented by a centralized governance regime using top-down schemes, and are characterized by poor negotiation with local planners and insufficient participation of local communities in final decision making [16]. 'Hard' planning dimensions (e.g., economic and finance issues, locational, engineering and legal aspects) are fundamental to such social housing initiatives. Although individual experiences of public housing vary significantly with their socioeconomic, political, and cultural contexts, top-down housing policies in emerging economies seem to reproduce (or even anticipate) some of the critical issues typical 
of social housing in developed countries [17-19]. Rethinking social housing in emerging economies to achieve truly cooperative and participative practices is a possible solution to such issues, evidence indicates the role of 'soft' planning dimensions (e.g. socio-cultural aspects, urban/architectural design, managerial issues) as being important alongside the frequently considered 'hard' dimensions [20].

As one of the most dynamic economies emerging in the world, Iran is facing an increasingly severe housing shortage. Due to the rapid growth of the urban population and the drastic changes in the structures of towns and cities in recent decades [21], a nationwide housing shortage, which is also associated with low quality housing, is an important socioeconomic issue in Iran. Providing affordable housing for low-income groups is regarded as a pivotal task of any policy or strategy due to the severity of housing conditions in many urban areas because of high household densities, restricted housing availability, and rapid growth in housing costs [22]. In the past three decades, strategic policies have been proposed to address the issue of housing shortages, especially housing for lower income populations. Despite the partial success of such initiatives, housing policies in Iran have not been able to address the housing shortages adequately [23].

With the housing price jump in 2006-2007, the government introduced a strategic national plan, the so-called 'Mehr Housing'. While envisioning a socialist view aimed at providing residential units for all households, this plan has regulated land prices, as this is considered to be the most relevant dimension affecting housing supply [24]. Assuming that temporary increases in dwelling market values-such as those observed in 2006-2007 in Iran - were associated with land value volatility [25], the Mehr Housing Plan was specifically designed with the aim of improving the access of low-income populations to Mehr housing, thereby neutralizing the effects of land prices [21]. Additional measures facilitating access of low-income households to housing included loan provision at reduced rates, a huge reduction in the cost of building permits, and subsidies for the costs of construction, i.e., preparing land, infrastructure, and materials [22].

With the completion of the Mehr Housing Plan, weaknesses, strengths, advantages, and shortcomings have been assessed [1]. Studies with positive evaluations of the plan have outlined some of the benefits, including more effective urban land reform, economic growth, increased employment levels, control of the general levels of land and housing prices, increased housing availability, improved household density in residential units, improved construction quality, and promotion of social justice $[2,21]$. This is in line with evidence from some European cities, especially in the Northern Mediterranean region and in Eastern European countries [12,13,26-32]. Shortcomings of the plan have included a weak policy approach to the conservation of the pristine structure of cities, promoting new dwellings outside the statutory city limits, and increased building costs [33]. Other issues have included a failure to target low-income households (because target groups have not been clearly identified), inappropriate locations, supply issues, lack of support infrastructure, and dissatisfaction of applicants with various social, economic, legal, and physical aspects of the plan [34-36]. Problems have also arisen because of a shortfall in financial resources for the plan, its negative effects on microand macro-economic factors across the country (i.e., increased liquidity and inflation), an increasingly imbalanced private housing market, and inadequate consideration of climatic and socio-cultural background of the country's different regions [37-39].

Despite the fact that the number of applications has been relatively low in some parts of the country, the Mehr Housing Plan has been a core issue in the national debate on urban development [40-42]. Although there are conflicting statistics on the number of empty houses built under Mehr planning, official sources state that nearly 100,000-150,000 dwellings were not assigned because nobody applied for them. The low appeal of these dwelling units in local communities-and especially to low-income populations-depends on multiple factors that require a detailed investigation. In this regard, the Mehr initiative represents a particularly emblematic social policy in an emerging economy for eligible people, financial resources, and the intrinsically complex operational characteristics. Based on a top-down strategy, the Mehr housing initiative was based on general rules and guidelines that emanated from the central authority and was directed to various intermediate levels, and only theoretically assuring 
compliance with the specific demands of regional and local communities [43]. Considering the articulated design that tried to integrate top-down policies and bottom-up negotiations/interactions, the present study attempts to identify the most important reasons for the ineffectiveness of the Mehr Housing Plan in Iran. This is based on a survey aimed at collecting specific information on beliefs and perceptions of the final stakeholders involved in the project's implementation. The results of this study provide direct and indirect evidence of strengths and weaknesses of social housing plans in emerging countries, outlining the role of top-down policies and the increasing importance of local contexts, cultural assets, architectural design, and environmental issues. Though initially regarded as 'soft' dimensions of dissatisfaction in public housing initiatives when compared with 'hard' dimensions such as costs, bureaucracy, engineering standards, and physical infrastructures, these issues require an increased amount of attention in urban policy-making and planning that is oriented toward truly sustainable and affordable housing.

\subsection{Low-Income Housing Policies in Iran}

Over the last few decades, the Iranian government has tried to deal with low-income housing in a mostly centralized way, using with a strategy based on two distinctive approaches: (i) operational measures supporting land provision to specific categories of stakeholders (e.g., individuals or housing cooperatives) under fixed prices, generally using regional-based criteria; and (ii) housing initiatives with specific focus on tenure (e.g., balancing property and rent), especially through hire purchase [44]. The expected performance of these two approaches was to build more than one million dwelling units on land allocated to individuals, cooperatives and constructors. However, a rapid increase of land prices in suburban locations has restricted the effectiveness of these interventions. Overall, about 120,000 dwelling units were released, consolidating a gap between the observed and the expected performances of housing policies in the country [45]. More specifically, social housing has been a major issue for central government in Iran since the Islamic Revolution, and various policies have been introduced to this end. Specific measures included state land allotment, hire purchase, and support to large constructors and low-income classes [46].

\subsection{Mehr Housing Program}

The Mehr Housing Plan, established on behalf of the Ministry of Roads and Urban Development, was a new policy strategy aimed at providing housing for low-income populations [1]. Based on land acquisition rights for small housing units with an average area of $75 \mathrm{~m}^{2}$, the plan aimed to reduce the impact of land costs, and to fit with the limited financial capacity of low-income and middle-income households [43]. According to this plan, all applicants who did not own dwellings (including government employees, people employed by private businesses, and the self-employed) organized themselves into housing cooperatives following the guidelines provided by specific technical offices operating in each city and province. These cooperatives presented specific projects to the Housing and Urban Ministry [2]. In response, the government offered loans of US\$1000 in two tranches (the first tranche of US\$100 to cover land preparation, and the remaining amount covering part of construction activities). After delivery of the housing units, the loan was repaid over a 15-year time horizon based on a given financial plan [44].

Since 2005, a recession in the housing market has forced the government to decrease mortgage rates with the aim of stimulating house demand. This policy influenced consumer prices in the country, and has led subsequently to an increase in house prices. Based on these new conditions, the government's policy shifted from demand promotion (via increased purchasing) to indirect support of building construction [33]. Specific measures under the Mehr Housing Plan were introduced in 2007 with the aim of providing adequate housing for low-income groups [34]. To achieve this goal, various strategies-including free allocation of public land and the containment of land prices from the cost of residential units-were proposed [35]. From the beginning of 2007 to February 2013, more than 388,538 Mehr Housing projects were implemented and nearly two million residential units were 
constructed [36]. Moreover, Mehr Housing projects promoted construction in 1135 towns and 18 new cities across the country. Cities within the Mehr Housing project were classified into three major groups based on population size ( $>25,000$ residents, $<25,000$ residents, and completely new towns). The distribution of Mehr units in these three groups was 48 per cent in cities with >25,000 inhabitants, 49 per cent in cities with $<25,000$ inhabitants, and 3 per cent in completely new cities [45]. The largest land plots under Mehr Housing projects had average areas between 100 and $200 \mathrm{~m}^{2}$ (44 per cent of all projects), and 29 per cent has areas between 200 and $300 \mathrm{~m}^{2}$. Only 12 per cent of total projects were developed on plots $>700 \mathrm{~m}^{2}$, and 5 per cent of projects had plots $<100 \mathrm{~m}^{2}$. The majority of small-scale plots were self-owned construction projects [46].

Analysis of the socioeconomic profile of Mehr Housing applicants (Table 1) illustrates a high rate of participation of young families with the head of the household $<34$ years $(64 \%)$. Female applicants (mostly self-employees $<35$ years) amounted for $14 \%$ of total applications. With the implementation of the Mehr Housing Plan, some new eligibility conditions were considered, including handicapped people, people receiving prizes or medals from the state because of their work, military service, or sporting accomplishments, and individuals covered by sponsoring institutions. Marital status was a non-compulsory requisite for these groups. The per cent share of married applicants was $89 \%$ of the total number of successful applicants: there were nearly 127,000 successful 'single' status applicants. Education level was recorded for $71 \%$ of the total applicants, and only $15 \%$ the surveyed applicants had a secondary school certificate. Civil servants were the largest working group within Mehr Housing (26 percent of applicants). Self-employees and those employed in the private sector were $23 \%$ and $22 \%$ of total applicants, respectively. The average income of applicants was US\$210 per month. Applicants earning < US\$200 per month accounted for 58\% of total applicants, while about $8 \%$ of applicants declared an income between US\$200 and US\$400 per month.

Table 1. Socioeconomic profile of applicants to the Mehr Housing Plan in Iran.

\begin{tabular}{|c|c|c|c|c|c|}
\hline Percentage & Group & & Percentage & Group & \\
\hline 14 & Illiterate & \multirow{4}{*}{ Education } & 33 & Under 25 years old & \multirow{6}{*}{ Age } \\
\hline 52 & $\begin{array}{l}\text { Primary/Sec. } \\
\text { school }\end{array}$ & & 31 & Between 25 and 34 years old & \\
\hline 5 & $\begin{array}{l}\text { Bachelor and } \\
\text { Upper }\end{array}$ & & 17 & 35 to 44 years old & \\
\hline 29 & Unknown & & 9 & 45 to 54 years old & \\
\hline 87 & Household head & \multirow{3}{*}{$\begin{array}{c}\text { Dependency } \\
\text { Burden } \\
\text { Status }\end{array}$} & 2 & 55 to 64 years old & \\
\hline 10 & Self-head & & 6 & Upper 65 years old & \\
\hline 3 & Unknown & & 86 & Male & \multirow{2}{*}{ Gender } \\
\hline 89 & Married & \multirow{2}{*}{ Marital Status } & 14 & Female & \\
\hline 11 & Single & & 22 & Worker & \multirow{6}{*}{ Occupation } \\
\hline 58 & Less than US\$200 & & 26 & Employee (Retirees, & \\
\hline 8 & US\$200-400 & & & Pensioners) & \\
\hline 3 & US\$400-800 & & 23 & Self-employed & \\
\hline 7 & $>\mathrm{US} \$ 800$ & & 29 & Unknown & \\
\hline 24 & IAN & & & & \\
\hline
\end{tabular}

\section{Methodology}

The present study introduces a descriptive and exploratory approach using literature review and primary data collected through a field survey. This survey was based on a questionnaire registering basic aspects of the research derived from a literature review that identified 33 items organized in six thematic dimensions (i.e., physical, economic, socio-cultural, institutional-managerial, legal, and locational) contributing to the overall dissatisfaction with Mehr Housing initiatives. Each item reflects a particular aspect of social housing (Table 2). The questionnaire recorded the level of agreement 
(ranging from very low to very high using a 5-step Likert scale) with each item. A total of 50 experts (technicians) operating continuously in Mehr Housing projects, were asked to participate in the study; 45 completed the questionnaire. The socioeconomic profile of respondents is illustrated in Table 3. This sample was representative of the different regions of the country where Mehr initiatives had been carried out. Structural equation modeling, a statistical technique that combines the measurement model (confirmatory and analytical) and regression (or path analysis) with simultaneous statistical testing, was used to explore field results [47]. This analysis was aimed at rejecting hypothetical structures (i.e., models) or reconcile them with survey data [48,49]. Data analysis was carried out using SMART-PLS software providing structural equation models with several variables including direct, indirect, and interactive effects.

Table 2. Issues of dissatisfaction with the Mehr Housing Plan in Iran and the related literature sources.

\begin{tabular}{|c|c|}
\hline Indicator & $\begin{array}{l}\text { Literature } \\
\text { Source }\end{array}$ \\
\hline Impossibility of changing dwelling structure & 33 \\
\hline Aesthetic homologation & $33,50,60$ \\
\hline Not paying attention to microclimate issues in housing design & 40,59 \\
\hline Not using the native architectural features & $34,35,51$ \\
\hline Lack of infrastructural services & $1,2,33,36,52$ \\
\hline Lack of internal solidity of residential buildings against accidents & $35,37,52,53$ \\
\hline Non-compliance with engineering/system national standards & $1,36,52,54$ \\
\hline Lack of shared space in buildings, especially yards & 46,54 \\
\hline Disproportionate balance of income of applicants with housing prices & $33,37,53,55$ \\
\hline Lack of adequate resources and credits for banks and financial institutions operating within Mehr Housing & 38,51 \\
\hline Not paying attention to the employment of residents in Mehr Housing projects & $41-43$ \\
\hline Weak provision of bank facilities & $35,36,39$ \\
\hline Increase in final price over the promised price & 33,3756, \\
\hline Disproportionate amount costs for type and quality of housing & $35,44,57$ \\
\hline Inadequate awareness of applicants to urbanization & Expert opinion \\
\hline Lack of trust in Mehr Housing companies and contractors & 45,46 \\
\hline Not paying attention to the household size in residential areas & $1,2,34,58$ \\
\hline Inadequate housing type with people's culture and faith & $39,56,59$ \\
\hline Not having hope in the future of Mehr Housing & 40,60 \\
\hline Negative attitude of the people towards a specific Mehr Housing project & 46 \\
\hline Lack of cultural and social convergence & $33,40,43,50$ \\
\hline Difficulty in transferring the property title & 52 \\
\hline Failing on-time delivery of completed houses & $43,46,51$ \\
\hline Lack of monitoring performances of contractors and housing cooperatives & 45 \\
\hline Intrinsic political orientation of the project & Expert opinion \\
\hline Lack of coordination within the responsible organizations & $40,43,56$ \\
\hline The simultaneous involvement of several institutions and organizations with poorly defined roles & $1,36,43,44$ \\
\hline Unclear ownership title & 53 \\
\hline Legal status of land and buildings & 53 \\
\hline Status (performance warranties) of assignment contracts & 53 \\
\hline Distance from the main city & $2,33,54$ \\
\hline Poor accessibility & 1,34 \\
\hline Lack of attention to environmental issues & $31-33,40-43$ \\
\hline
\end{tabular}

Table 3. Socioeconomic profile of respondents.

\begin{tabular}{|c|c|c|c|c|c|c|c|c|c|c|c|}
\hline Age & $\%$ & Number & Gender & $\%$ & Number & Education & $\%$ & Number & Experience (Year) & $\%$ & Number \\
\hline $25-35$ & $60-0$ & 27 & Male & 60.0 & 27 & Bachelor & 15.6 & 7 & $1-5$ & 22.2 & 10 \\
\hline $36-45$ & 31.5 & 12 & Female & 37.7 & 18 & Master & 6.0 & 27 & $6-10$ & 17.8 & 8 \\
\hline+46 & 8.9 & 4 & Not respires & 2.2 & 1 & Doctorate & 24.4 & 11 & +10 & 13.3 & 6 \\
\hline
\end{tabular}

\section{Results}

Most respondents (60\%) were young (25-35 years old) and male (60\%). Nearly $85 \%$ of respondents had a Master's degree or higher qualification, and more than five years work experience (Table 3).

Within the six analytical dimensions, respondents ranked location (average score: 4.08) and institutional-managerial problems (3.70) as the most important weaknesses of the Mehr Housing Plan. Socio-cultural (3.42), economic (3.38), physical (3.38), and legal aspects (3.18) received, on average, lower scores indicating a less evident average dissatisfaction with such dimensions. However, particularly high dissatisfaction was observed for specific items listed in Table 2. These were lack of 
infrastructures (4.57), non-delivery of housing in the promised time frame (4.26), poor accessibility (4.17), environmental aspects (4.13), average dwelling size (4.08), and the unexpected increase in final price (4.00) were the most significant of these factors (Table 4).

Table 4. Influence of research dimensions and questionnaire items (indicators) on the overall level of dissatisfaction with the Mehr Housing Plan according to expert opinions.

\begin{tabular}{|c|c|c|c|c|c|c|c|}
\hline \multirow{2}{*}{ Average Rate } & \multicolumn{5}{|c|}{ Overall Impact on Dissatisfaction Level } & \multirow{2}{*}{ Item } & \multirow{2}{*}{ Dimensions } \\
\hline & Very High & High & Moderate & Low & Very Low & & \\
\hline 2.58 & 0 & 13.3 & 46.7 & 24.4 & 15.6 & Impossibility of changing house structure & \multirow{9}{*}{ Physical } \\
\hline 3.26 & 24.4 & 26.7 & 13.3 & 22.2 & 13.3 & \multirow{8}{*}{$\begin{array}{l}\text { Homogenization in housing design } \\
\text { Not paying attention to micro-climate of housing } \\
\text { Not using the native architecture features } \\
\text { Lack of infrastructure and services } \\
\text { Lack of solidity of buildings against hazards } \\
\text { Failure to comply with national system standards } \\
\text { Lack of space in buildings, especially yards } \\
\text { Average physical dimension }\end{array}$} & \\
\hline 3.46 & 15.6 & 42.2 & 22.2 & 13.3 & 6.7 & & \\
\hline 3.00 & 13.3 & 31.1 & 13.3 & 26.7 & 15.6 & & \\
\hline 4.57 & 64.4 & 33.3 & 0 & 0 & 2.2 & & \\
\hline 3.84 & 44.4 & 11.1 & 33.3 & 6.7 & 4.4 & & \\
\hline 3.50 & 28.9 & 22.2 & 24.4 & 17.8 & 6.7 & & \\
\hline 3.35 & 22.2 & 20.0 & 31.1 & 24.4 & 2.2 & & \\
\hline 3.38 & 24.4 & 24.1 & 25.1 & 17.0 & 9.1 & & \\
\hline 2.82 & 6.7 & 17.8 & 42.2 & 17.8 & 15.6 & Impossibility of developing houses & \multirow{7}{*}{ Economic } \\
\hline 3.15 & 15.6 & 22.2 & 31.1 & 24.4 & 6.7 & $\begin{array}{l}\text { Lack of sufficient resources and credits of banks and } \\
\text { financial institutions }\end{array}$ & \\
\hline 3.40 & 15.6 & 3.33 & 3.33 & 11.1 & 6.7 & Not paying attention to the occupation of residents & \\
\hline 3.40 & 15.6 & 31.1 & 37.8 & 8.9 & 6.7 & \multirow{4}{*}{$\begin{array}{c}\text { Weakness of bank facilities } \\
\text { Increase in final price over promised price } \\
\text { Disproportionate amount of cost with type and quality of } \\
\text { housing } \\
\text { Average economic dimension }\end{array}$} & \\
\hline 4.00 & 3.33 & 40.0 & 20.0 & 6.7 & 0 & & \\
\hline 3.53 & 22.2 & 33.3 & 26.7 & 11.1 & 6.7 & & \\
\hline 3.38 & 18.1 & 29.6 & 31.8 & 13.3 & 7.0 & & \\
\hline 2.65 & 2.2 & 15.6 & 44.4 & 24.4 & 13.3 & \multirow{8}{*}{$\begin{array}{l}\text { Not paying attention to the household size } \\
\text { Disparity between housing and people's morale } \\
\text { Lack of hope for the future of Mehr housing } \\
\text { Negative view of the people regarding Mehr Housing } \\
\text { Lack of cultural and social convergence } \\
\text { Average sociocultural dimension }\end{array}$} & \multirow{8}{*}{ Sociocultural } \\
\hline 3.57 & 13.3 & 44.4 & 28.9 & 13.3 & 0 & & \\
\hline 3.53 & 26.7 & 31.1 & 17.8 & 17.8 & 6.7 & & \\
\hline 3.62 & 24.4 & 44.4 & 6.7 & 17.8 & 6.7 & & \\
\hline 3.37 & 17.8 & 35.6 & 20.0 & 20.0 & 6.7 & & \\
\hline 3.60 & 24.4 & 31.1 & 31.1 & 6.7 & 6.7 & & \\
\hline 3.60 & 17.8 & 48.9 & 13.3 & 15.6 & 4.4 & & \\
\hline 3.42 & 18.0 & 35.8 & 23.1 & 16.5 & 6.3 & & \\
\hline 3.64 & 20 & 44.4 & 17.8 & 15.6 & 2.2 & How to lease housing & \multirow{7}{*}{$\begin{array}{l}\text { Institutional } \\
\text { and } \\
\text { managerial }\end{array}$} \\
\hline 4.26 & 44.4 & 40 & 13.3 & 2.2 & 0 & Non-timely allocation of dwellings & \\
\hline 3.77 & 26.7 & 37.8 & 24.4 & 8.9 & 2.2 & $\begin{array}{l}\text { Lack of monitoring of the performance of contractors and } \\
\text { housing cooperatives }\end{array}$ & \\
\hline 3.20 & 13.3 & 26.7 & 33.3 & 20.0 & 6.7 & Centralized politics of the Mehr housing plan & \\
\hline 3.79 & 28.9 & 37.8 & 117.8 & 11.1 & 4.4 & Non-coordination of the responsible organizations & \\
\hline 3.53 & 24.4 & 24.4 & 31.1 & 17.8 & 2.2 & Lack of institutional coordination & \\
\hline 3.70 & 26.3 & 35.2 & 22.9 & 12.6 & 2.9 & Average institutional and managerial dimension & \\
\hline 3.06 & 11.1 & 24.4 & 31.1 & 26.7 & 6.7 & Type of ownership of houses & \multirow{4}{*}{ legal } \\
\hline 3.09 & 6.7 & 31.1 & 31.1 & 26.7 & 4.4 & Legal status of land and buildings & \\
\hline 3.40 & 17.8 & 22.2 & 42.2 & 17.8 & 0 & Status (execution guarantee) Housing Contracts & \\
\hline 3.18 & 11.8 & 26.9 & 34.8 & 23.7 & 3.7 & Average legal dimension & \\
\hline 3.93 & 28.9 & 42.2 & 22.2 & 6.7 & 0 & Distance from the main city & \multirow{4}{*}{ location } \\
\hline 4.17 & 40 & 42.2 & 133 & 4.4 & 0 & Geographic position of the settlement & \\
\hline 4.13 & 4.44 & 31.1 & 15.6 & 8.9 & 0 & Lack of attention to environmental issues & \\
\hline $4 . .08$ & 37.7 & 38.5 & 17.0 & 6.6 & 0 & Average dwelling dimension & \\
\hline
\end{tabular}

In order to verify the validity and stability of results such as these, Frenel and Larker (1981) introduced three statistics: (i) Lacre's rate, which estimates the validity of each surveyed item; (ii) the Composite Reliability (CR) of each construct; and (iii) the Average Extracted Variance (AVE). Regarding the validity of each item, a loading of $>0.4$ in the confirmatory factor analysis indicated that the variance between the concept and the related variables was greater than the variance of the measurement error of the concept, suggesting that a model's reliability is acceptable [50-55]. To assess the reliability of the questionnaire, internal consistency and convergent validity were considered. Internal consistency was adopted to verify the reliability of measures. Table 5 shows the coefficients of internal consistency. All coefficients of composite reliability and Cronbach's alpha were $>0.7$, and the average variance extracted was $>0.4$, indicating an acceptable representation of measures. 
Table 5. Reliability and convergent validity coefficients (AVE: Average Extracted Variance).

\begin{tabular}{cccc}
\hline AVE & Composite Reliability & Cronbach's Alpha & Variable \\
\hline $\mathbf{0 . 4 6 1}$ & 0.853 & 0.794 & Socio-cultural \\
$\mathbf{0 . 5 1 3}$ & 0.840 & 0.767 & Economic \\
$\mathbf{0 . 5 8 4}$ & 0.807 & 0.645 & Legal \\
$\mathbf{0 . 6 3 4}$ & 0.836 & 0.704 & Location \\
$\mathbf{0 . 4 8 1}$ & 0.845 & 0.777 & Institutional and managerial \\
$\mathbf{0 . 4 8 1}$ & 0.846 & 0.787 & Physical \\
\hline
\end{tabular}

Factor loadings illustrating the multivariate relationships between research dimensions were systematically above 1.96, outlining significant correlations at a $95 \%$ confidence level. By examining the individual effect of each dimension of dissatisfaction with Mehr Housing local initiatives, a relationship between each of the dimensions of dissatisfaction was observed (Figure 1).

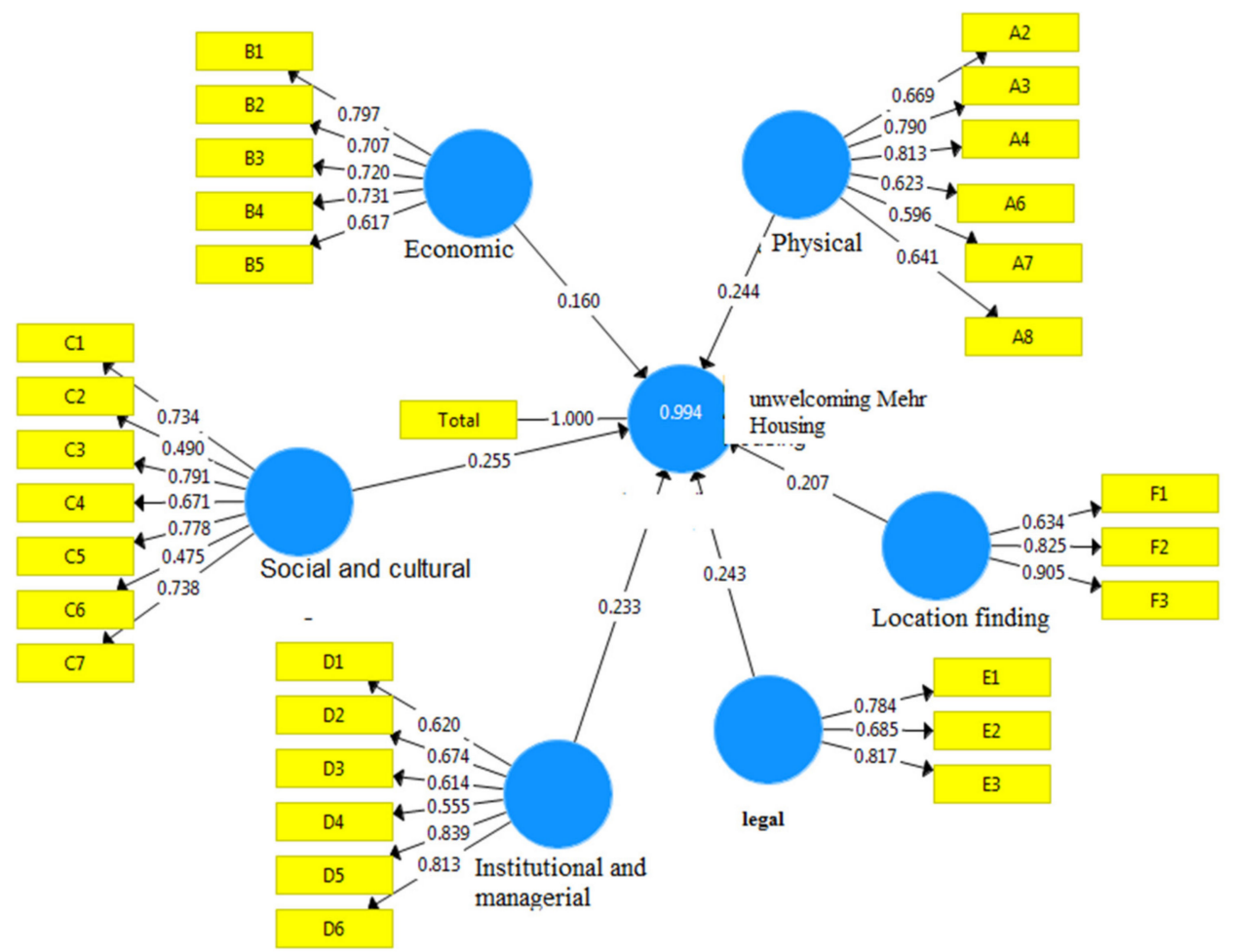

Figure 1. Results of a structural equation model assessing relationships between variables (see Table 4 for list of variables).

Socio-cultural, physical, legal, and institutional-managerial factors were, on average, well correlated most with the other dimensions. Location and economic dimensions seem to be less well associated with the other dimensions. At the same time, each dimension can contribute differently to the overall level of dissatisfaction with local Mehr Housing initiatives. Legal and socio-cultural dimensions had the highest impacts on dissatisfaction on local initiatives, followed by the institutional-managerial and location dimensions (Table 6). 
Table 6. Results of a structural equation model applied to dissatisfaction with local Mehr Housing plans.

\begin{tabular}{lccccc}
\hline \multicolumn{1}{c}{ Issue } & T Statistic & $\boldsymbol{p}$-Value & $\begin{array}{c}\text { Sample } \\
\text { Average }\end{array}$ & $\begin{array}{c}\text { Standard } \\
\text { Deviation }\end{array}$ & $\begin{array}{c}\text { Path } \\
\text { Coefficient }\end{array}$ \\
\hline Socio-cultural & 7.015 & $<0.001$ & 0.249 & 0.036 & 0.255 \\
Economic & 5.479 & $<0.001$ & 0.154 & 0.029 & 0.160 \\
Legal & 7.326 & $<0.001$ & 0.251 & 0.033 & 0.243 \\
Location & 6.470 & $<0.001$ & 0.202 & 0.032 & 0.207 \\
Institution/management & 6.614 & $<0.001$ & 0.225 & 0.035 & 0.233 \\
Physical/territorial & 5.947 & $<0.001$ & 0.242 & 0.041 & 0.244 \\
\hline
\end{tabular}

\section{Discussion}

Housing is one of the basic needs of human society. To meet this need, local communities and the relevant authorities play key roles in housing policy [7]. Social housing is considered a key issue in urban management all over the world $[8,9,15]$. In line with changing socioeconomic conditions and political conditions in emerging countries [16], authorities have tried to implement policies to mitigate housing shortages and to improve the quality of dwellings [18-20]. At the same time, construction is one of the most important industries in these countries, and it contributes significantly to economic growth and societal wellbeing [50]. In an emerging economy like Iran, the Mehr Housing Project has been the most important social housing plan for low-income populations [51-53]. With the introduction of this program, housing prices were reduced by reducing construction costs and stabilizing land prices [54]. More specifically, the program was aimed at balancing supply and demand, and increasing the availability of affordable housing especially in smaller towns [55]. However, with the completion of most of the local Mehr Housing initiatives across the country, satisfaction with the plan has been relatively low and the number of applicants for a 'Mehr house' was modest irrespective of the local context [56].

Six dimensions articulated as 33 specific items were considered as important factors of dissatisfaction with Mehr Housing plan in this study [33]. Based on descriptive statistics, the empirical results of this study showed that all six dimensions impacted the overall level of dissatisfaction, indicating a generalized weakness in the Mehr Housing Plan [34]. Location was identified as a basic dimension of dissatisfaction with Mehr Housing initiatives, since Mehr settlements are often regarded as too decentralized with low accessibility to downtown areas [39,57]. This finding outlines the importance of a practical match between social housing policies and a general plan for infrastructure, public transport, and improvements in leisure facilities and amenities in new settlements $[43,45,58]$. In line with earlier research [32], the institutional-managerial dimension was another important issue leading dissatisfaction with Mehr housing. Bureaucracy (e.g., requests for multiple documents, permits, and authorizations), lack of consistency between planned and realized dwellings, untimely release of new houses, and non-compliance with national regulations as far as structural stability and dwelling safety, were particularly important issues in preventing a positive judgment on local Mehr housing initiatives [33]. This evidence suggests a progressive decoupling between the strict national-level guidelines for the regulation of Mehr projects and operations at the local scale (the individual Mehr housing initiatives) and confirms earlier findings [43].

The socio-cultural dimension was the third most important issue of dissatisfaction [50]. Lack of attention to household size and the resulting effects on socio-cultural cohesion in the new settlements was an important issue fueling dissatisfaction with the plan [59-65]. Lack of awareness of the applicants about future urbanization surrounding the new settlements, and a general lack of trust in Mehr Housing actors, also played role in this dimension [51]. Taken together, these results suggest that social housing strategies should incorporate programs for ameliorating both the infrastructure and environment around residential settlements [52]. Urban design of social housing should be also more clearly oriented toward well-being and cohesion of local communities [65]. In fact, issues characterizing the physical dimension of social housing (e.g., architectural standardization; lack of shared spaces in buildings, 
especially yards; poor attention to accidents that might occur in residential buildings) were other factors reducing levels of satisfaction [43].

Together with the results of descriptive statistics, results of the exploratory data analysis suggest how 'soft' factors, e.g., those included in the socio-cultural dimension, are intrinsically related with the 'hard' engineering-legal-managerial dimensions of Mehr public housing. At the same time, these findings may indicate how location and economic aspects-while being important dimensions shaping the overall dissatisfaction with Mehr Housing initiatives-are less associated with the other dimensions. They may represent a sort of background context when evaluating social housing, irrespective of the other dimensions [66-68]. These results seem to be coherent with the rationale of Mehr Housing initiatives, which are mostly designed for direct or indirect economic support of households (e.g., land and house price regulation). The less important role of the economic dimension in the overall dissatisfaction with Mehr Housing can be explained by the fact that the Mehr Housing Plan was oriented from the beginning toward subsidizing low-income populations [1]. However, other aspects-which have been less carefully considered in national regulations and guidelines - are key in the overall levels of dissatisfaction with Mehr housing. This likely accounts for the relatively low number of applications for local Mehr initiatives, even among low-income groups [63-65].

\section{Conclusions}

While not being integral to national policies and local initiatives, 'soft' factors including socio-cultural and architectural aspects are still important factors shaping satisfaction with any program of social housing in traditional societies. Our study confirms the urgent need to rethink urban planning and social policies in emerging economies so that truly cooperative and participatory practices, e.g., linking public housing more explicitly with the broader issue of quality of life in urban areas [69-71]. Policy design based on a participatory strategy is the only solution to overcome problems $[72,73]$ such as substantially improving the effectiveness of social housing plans. Empirical research should provide a more comprehensive — and possibly comparative-overview of multiple factors shaping satisfaction (or dissatisfaction) with public housing programs based on a standardized classification of dimensions and items. However, it must be flexible enough to identify characteristics and needs of local communities [74,75].

The intrinsic linkage with the private construction sector and, more generally, with urban planning, sustainable development strategies, and policies addressing quality of life in metropolitan regions, should be clearly outlined through use of field surveys, analysis of secondary data, and literature reviews. A refined analysis distinguishing 'structural' factors (e.g., economic, engineering, locational) from place-based dimensions (e.g., socio-cultural, legal, managerial) shaping levels of (dis)satisfaction with social housing may clarify the roles of national guidelines and the importance of regional articulation of centralized programs to various local contexts. Such studies will contribute widely by trying to reconnect top-down planning with the most appropriate bottom-up initiatives, thereby giving value to local communities' needs, and providing long-term positive impacts on quality of life and sustainable development in urban areas.

Author Contributions: Conceptualization, S.Z.S. and H.F.; methodology, B.F.M. and A.H.; software, Y.A. and V.A.F.; validation, E.F. and H.F.; formal analysis, B.F.M., N.A. and A.H.; investigation, Y.A. and V.A.F.; resources, S.C. and S.V.; data curation, E.F. and H.F.; writing-original draft preparation, L.S., S.Z.S. and N.A.; writing-review and editing, N.A., S.C. and S.V.; visualization, B.F.M.; supervision, Y.A.; project administration, S.V.; funding acquisition, S.C. All authors have read and agreed to the published version of the manuscript.

Funding: This research received no external funding.

Conflicts of Interest: The authors declare no conflict of interest.

\section{References}

1. Nastaran, M.; Ranaei, A. The Analysis of Participation's Implication in "Mehr" Land Developing Projects. Arman. J. 2010, 3, 111-124. 
2. Pourmohamdi, M. Housing Planning, 10th ed.; Samt: Tehran, Iran, 2010.

3. Hunt, B.D. Was the 1937 U.S. Housing Act a Pyrrhic Victory? J. Plan. Hist. 2005, 4, 195-221. [CrossRef]

4. Radford, G. Modern Housing for America: Policy Struggles in the New Deal Era; University of Chicago Press: Chicago, IL, USA, 1996.

5. Shester, K.L. The Local Economic Effects of Public Housing in the United States, 1940-1970. J. Econ. Hist. 2013, 73, 978-1016. [CrossRef]

6. Vale, L.J. From the Puritans to the Projects: Public Housing and Public Neighbors; Harvard University Press: Cambridge, MA, USA, 2000.

7. Vale, L.J. Reclaiming Public Housing: A Half Century of Struggle in Three Public Neighborhoods; Harvard University Press: Cambridge, MA, USA, 2002.

8. Scanlon, K.; Fernández Arrigoitia, M.; Whitehead, C.M. Social housing in Europe. European Policy Analysis 2005, 17, 1-12.

9. Scanlon, K.; Whitehead, C.; Arrigoitia, M.F. Social Housing in Europe; Wiley: London, UK, 2014.

10. Whitehead, C.M.; London, L.S.E. Financing social housing in Europe. Hous. Financ. Int. 2003, 17, 3-8.

11. Oxley, M.; Elsinga, M.; Haffner, M.; Van Der Heijden, H. Competition and social housing in Europe. Econ. Aff. 2008, 28, 31-36. [CrossRef]

12. Tsenkova, S.; Turner, B. The future of social housing in Eastern Europe: Reforms in Latvia and Ukraine. Eur. J. Hous. Policy 2004, 4, 133-149. [CrossRef]

13. Hegedus, J.; Lux, M.; Teller, N. Social Housing in Transition Countries (Vol. 10); Routledge: London, UK, 2013.

14. Oxley, M.; Smith, J. Housing Policy and Rented Housing in Europe; Taylor \& Francis: London, UK, 1996.

15. Malpass, P. istories of Social Housing: A Comparative Approach. In Social Housing in Europe, Real Estate Issue; Routledge: London, UK, 2014; pp. 259-294.

16. Wang, Y.P.; Murie, A. The new affordable and social housing provision system in China: Implications for comparative housing studies. Int. J. Hous. Policy 2011, 11, 237-254. [CrossRef]

17. Taylor, M. Combating the social exclusion of housing estates. Hous. Stud. 1998, 13, 819-832. [CrossRef]

18. Bardhan, A.; Edelstein, R.H. Housing finance in emerging economies: Applying a benchmark from developed countries. In Mortgage Markets Worldwide; Sage: London, UK, 2008; p. 231.

19. Salzer, C.; Wallbaum, H.; Ostermeyer, Y.; Kono, J. Environmental performance of social housing in emerging economies: Life cycle assessment of conventional and alternative construction methods in the Philippines. Int. J. Life Cycle Assess. 2017, 22, 1785-1801. [CrossRef]

20. Wang, Y.P. Urban Poverty, Housing and Social Change in China; Routledge: London, UK, 2004.

21. Bid Abadian, H.; Mahmood Zadeh, A. Economic and Social Pathology of Mehr Housing Project. In Proceedings of the International Human Conference, Architecture, Civil and Urban, Tabriz, Iran, 2 June 2015.

22. Gholizadeh, A.; Aghigh, B. Land leverage and housing price volatility in Iran. Appl. Econ. Stud. Iran 2015, 4, $49-67$.

23. Asgari, M.; Baghdadi, A. Evaluating the Relative Efficiency of Mehr housing plan in selected cities of Tehran Province. Q. J. Econ. Res. Policies 2017, 24, 119-142.

24. Somaalo, A. Mehr Housing structural rotation in housing policy and its achievements. Q. J. Hous. 2010, 47, 5-11.

25. Kazemzadeh-Zow, A.; Zanganeh Shahraki, S.; Salvati, L.; Samani, N.N. A spatial zoning approach to calibrate and validate urban growth models. Int. J. Geogr. Inf. Sci. 2017, 31, 763-782. [CrossRef]

26. Morelli, V.G.; Rontos, K.; Salvati, L. Between suburbanisation and re-urbanisation: Revisiting the urban life cycle in a Mediterranean compact city. Urban Res. Pract. 2014, 7, 74-88. [CrossRef]

27. Di Feliciantonio, C.; Salvati, L. 'Southern' Alternatives of Urban Diffusion: Investigating Settlement Characteristics and Socio-Economic Patterns in Three Mediterranean Regions. Tijdschrift voor Economische en Sociale Geografie 2015, 106, 453-470. [CrossRef]

28. Rontos, K.; Grigoriadis, E.; Sateriano, A.; Syrmali, M.; Vavouras, I.; Salvati, L. Lost in protest, found in segregation: Divided cities in the light of the 2015 "Oxı" referendum in Greece. City Cult. Soc. 2016, 7, 139-148. [CrossRef]

29. Salvati, L.; Sateriano, A.; Grigoriadis, E. Crisis and the city: Profiling urban growth under economic expansion and stagnation. Lett. Spat. Resour. Sci. 2016, 9, 329-342. [CrossRef]

30. Cuadrado-Ciuraneta, S.; Durà-Guimerà, A.; Salvati, L. Not only tourism: Unravelling suburbanization, second-home expansion and "rural" sprawl in Catalonia, Spain. Urban Geogr. 2017, 38, 66-89. [CrossRef] 
31. Zambon, I.; Serra, P.; Sauri, D.; Carlucci, M.; Salvati, L. Beyond the 'Mediterranean city': Socioeconomic disparities and urban sprawl in three Southern European cities. Geogr. Ann. Ser. B Hum. Geogr. 2017, 99, 319-337. [CrossRef]

32. Duvernoy, I.; Zambon, I.; Sateriano, A.; Salvati, L. Pictures from the other side of the fringe: Urban growth and peri-urban agriculture in a post-industrial city (Toulouse, France). J. Rural Stud. 2018, 57, 25-35. [CrossRef]

33. Habibi, K.; Behzadfar, M.; Torabi, K.; Mahaki, V. Criticism and Pathology of Policies and Planning of Mehr Housing in Iran. Abadi Q. 2010, 69, 6-13.

34. Hosseini, S.A. Pathology of Mehr Housing Project (Case Study: Mehr City of Sanqur). Master's Thesis, Imam Khomeini International University, Qazvin, Iran, 2015.

35. Ansari, H.A. Evaluation and Analysis of the Functionality of Residential Complexes Case Study: Mehr Housing Scheme (Ghadir Project). Honarhaye Ziba Memari Shahrsazi 2015, 20, 95-104.

36. Bahmani, A.; Ghaedrahmati, S. Evaluating the Mehr Housing Project in terms of Adequate Qualitative Indicators (Case Study: Mehr Housing Project of 22 Bahman, Zanjan). Geogr. Reg. Dev. 2017, 14, 47-65.

37. Razavian, M.T.; Haraeeni, M.; Bahrami, M.; Alizade, P. Assessment of indicators of social housing for citizens (Case study Mehr Housing Parand city). Geogr. Environ. Stud. 2018, 6, 51-64.

38. Hejazi, S.J. Analyzing Mass Housing Development User Satisfaction Maskane Mehr (Case Study: Mahshar Housing). Soc. Dev. 2014, 2, 239-256.

39. Khalili, A.; Nourallahi, H.; Rashidi, N.; Rahmani, M. Evaluation of Mehr Housing Policies in Iran and Presentation of Solutions for their Improvement. Urban Stud. 2015, 4, 83-92.

40. Babaei, M.A.; Ghorbanpur Rasekh Danesh, M. Aspects of Crime-proneness with regard to the Policy of Mehr Housing. Crim. Law 2015, 3, 33-56.

41. Bahrami, Y.; Iraj, G.; Oftadeh, B.; Hosieni, S.A. Checking Mehr housing development policies in the framework of infill development from View residents Mehr housing of Mahabad city. Res. Geogr. Sci. 2016, 16, 117-134.

42. Firoznia, M.; Nemati, M.; Daripoor, N. Evaluation of the Satisfaction Level of Residents of Maskan-e-Mehr in Khuzestan Province with an Emphasis on Sustainable Housing (Case Study: Omidiyeh County). J. Stud. Hum. Settl. Plan. 2017, 11, 53-66.

43. Ministry of Roads and Urban Development of the Islamic Republic of Iran. Report; Office of Planning and Housing Economy: Teheran, Iran, 2010.

44. Abbasi, H. Lack of planning in Iran's housing policies. J. Jastarhaye Shahri 2011, 35, 98.

45. Pourmohammadi, M.R.; Sadrmousavi, M.S.; Abedini, A. Analytical Consideration on Policies of Housing Supply by Government with Respect to the Cultural and Socioeconomic Development plans in Iran. Urban Stud. 2012, 1, 34-43.

46. Firooz, T. Report on Recognition, Documentation and Evaluation of Mehr Housing Plan; Office of Planning and Housing Economy: Teheran, Iran, 2014.

47. Schumacker, R.E.; Lomax, R.G. A Beginner's Guide to Structural Equation Modeling; Psychology Press: London, UK, 2004.

48. Munafò, M.; Salvati, L.; Zitti, M. Estimating soil sealing rate at national level-Italy as a case study. Ecol. Indic. 2013, 26, 137-140. [CrossRef]

49. Zitti, M.; Ferrara, C.; Perini, L.; Carlucci, M.; Salvati, L. Long-term urban growth and land use efficiency in Southern Europe: Implications for sustainable land management. Sustainability 2015, 7, 3359-3385. [CrossRef]

50. Ziari, K.; Arvin, M.; FarhadiKhah, H. Evaluation of Selected housing indexes in city (Case Study: Ahvaz). Urban Manag. Stud. 2017, 9, 49-63.

51. Gang Meng, G.; Brent, H. Assessing housing quality in metropolitan Lima, Peru. J. Hous. Built Environ. 2006, 21, 413-439. [CrossRef]

52. Nazemi, E.; Darodi, M. Study of quality housing quality indicators, in Mehr House Project (Case Study: Isfahan Province). In Proceedings of the First National Conference on Urbanism and Architecture over time, Qazvin, Iran, 1-2 September 2013.

53. Masoudirad, M.; Ebrahimzadeh, I.; Rafieian, M. Assessment of Mehr Housing Policy According to Sustainability Indicators Case study: Khorramabad City. Geogr. Envion. Plan. 2017, 28, 1-20.

54. Noori, R.; Boorboorajdari, M.; Boorboorajdari, M. Evaluating the Achievement of the Objectives of Mehr Housing Plan: Case Study of Pardis New City, Tehran. Urban Rural Manag. 2015, 15, 445-452. 
55. Shateriyan, M.; Kiyani Salmi, S.; Ghanbari, R. Assessment of the economic effects-Social and physical Mehr Housing views of residents (Case Study: Mehr Housing of Kashsn city). Geogr. Reg. Plan. 2017, 27, 109-126.

56. Moon-Jeong, K. Residential Location Decisions: Heterogeneity and the Trade-off between Location and Housing Quality; The Ohio State University: Columbus, OH, USA, 2010.

57. Zabetian, E.; Sadeghi, A.; Hosseinabadi, S. Measuring Resident Satisfaction in Mehr Housing Projects with Emphasis on Objective Aspects (Case Study: Mehr Housing Project in Qom City). J. Iran. Archit. Urban 2018, 8, 173-184.

58. Zanganeh, M.; Gharehmani, M.; Goudarzi, S.; Khalil, M. Measuring the Satisfaction of Residents with the Quality of Mehr Housing Project in Hamedan City. Haft Hesar. Environ. Stud. 2018, 6, 31-44.

59. Pourmohamadi, M.; Asadi, A. Evaluation of Mehr Housing Projects, Zanjan City, Tahghighat Karbordi. J. Appl. Geosci. Res. 2014, 14, 171-192.

60. Shahi Aqbelaghi, A.; Zanganeh, Y.; Khodabandehlo, H. Evaluation of the quality of urban environmental Factors, Case study: Housing Mehr, Sabzevar. Arid Reg. Geogr. Stud. 2017, 7, 54-72.

61. Sobhiyah, M.; Radaiee, R. The Realization of Objectives and Plans of "Maskan-e Mehr" program in Mahdasht Project. J. Baghe-E Nazar 2015, 12, 91-106.

62. Mazlome Khorasani, M.; Noghani, M.; Kishbafan, B.F. Participation rate of housing cooperation members (Mehr) and Explication effective factors on it in 1388 at Mashhad city. Appl. Sociol. 2012, 22, 131-152.

63. Rashid Nahal, M.; Karimian, S.M.; Rezaei, H. Maskan Mehr Cooperative; Payegan: Teheran, Iran, 2008.

64. Fallah, M.; Nasirifirooz, N. Legal Effects of Assignment of "Mehr Housing contract". Judic. Law J. 2013, 77, 223-257.

65. Daroudi, M.; Jahanshahloo, L.; Shahriary, S.K. Maskane Mehr residents' satisfaction measurement by city management approach (The case of Bustan complex in new Hashtgerd city). J. Urban Econ. Manag. 2015, 3, 125-141.

66. Mulder, C.H.; Lauster, N.T. Housing and Family: An Introduction. Hous. Stud. 2010, 25, 433-440. [CrossRef]

67. Gabriel, M.; Jacobs, K. The Post- Social Turn: Challenges for Housing Research. Hous. Stud. 2008, 23, 527-540. [CrossRef]

68. World Bank. The Housing Indicators Program: Extensive Survey, Part II; UNCHS and World Bank: Washington, DC, USA, 1992.

69. Kleinhans, R.; Elsinga, M. Buy Your Home and Feel in Control' Does Home Ownership Achieve the Empowerment of Former Tenants of Social Housing. Int. J. Hous. Policy 2010, 10, 41-61. [CrossRef]

70. Zebardast, E. The Housing Domain of Quality of Life and Life Satisfaction in the Spontaneous Settlement on the Tehran Metropolitan Fringe. Springer Sci. 2008, 90, 307-324. [CrossRef]

71. Van Gent, W.P.C. Housing Context and Social Transformation Strategies in Neighborhood Regeneration in Western European Cities. Int. J. Hous. Policy 2010, 10, 63-87. [CrossRef]

72. Bolt, G.; Phillips, D.; Van Kempen, R. Housing Policy, Desegregation and Social Mixing: An International Perspective. Hous. Stud. 2010, 25, 129-135. [CrossRef]

73. Carlucci, M.; Grigoriadis, E.; Rontos, K.; Salvati, L. Revisiting a hegemonic concept: Long-term 'Mediterranean urbanization' in between city re-polarization and metropolitan decline. Appl. Spat. Anal. Policy 2017, 10, 347-362. [CrossRef]

74. Carlucci, M.; Grigoriadis, E.; Venanzoni, G.; Salvati, L. Crisis-driven changes in construction patterns: Evidence from building permits in a Mediterranean city. Hous. Stud. 2018, 33, 1151-1174. [CrossRef]

75. Allen, J.; Barlow, J.; Leal, J.; Maloutas, T.; Padovani, L. Housing and Welfare in Southern Europe (Volume 16); Wiley: London, UK, 2008.

(C) 2020 by the authors. Licensee MDPI, Basel, Switzerland. This article is an open access article distributed under the terms and conditions of the Creative Commons Attribution (CC BY) license (http://creativecommons.org/licenses/by/4.0/). 